\title{
WPŁYW USYTUOWANIA BUDYNKU INWENTARSKIEGO NA UZYSK CIEPŁA SŁONECZNEGO
}

\author{
Krzysztof Wiśniewski ${ }^{1}$, Agata Pawłat-Zawrzykraj ${ }^{2} \bowtie$ \\ ${ }^{1}$ Instytut Inżynierii Lądowej, Szkoła Główna Gospodarstwa Wiejskiego w Warszawie \\ ${ }^{2}$ Instytut Inżynierii Środowiska, Szkoła Główna Gospodarstwa Wiejskiego w Warszawie
}

\begin{abstract}
STRESZCZENIE
Praca dotyczy wpływu usytuowania budynku inwentarskiego względem stron świat na absorpcję energii słonecznej, szczególnie w okresach niskiej i wysokiej temperatury na zewnętrz. Punktem wyjścia było zróżnicowanie przestrzenne w dystrybucji promieniowania słonecznego w Polsce. Wykorzystano metodykę wyznaczania zysków ciepła od promieniowania słonecznego zgodnie z normą PN-EN 13790. Obliczenia wykonano dla teoretycznego budynku chlewni dla czterech wariantów usytuowania rozpatrywanego budynku względem stron świata w osiach N-S, W-E, NW-SE oraz NE-SW. Przyjęto teoretyczne lokalizacje budynku w trzech strefach klimatycznych Polski: w strefie II reprezentowanej przez Poznań, w strefie III (Warszawa i Jelenia Góra) oraz w strefie IV (Białystok). Uzyskane wyniki nie potwierdziły w pełni trafności powszechnie stosowanej zasady sytuowania budynku w osi N-S. Niemniej jednak od kwietnia do września jest to lokalizacja rzeczywiście korzystna w niektórych strefa klimatycznych kraju (strefy II i IV). W okresach niskiej temperatury najbardziej optymalne jest usytuowanie w osiach W-E (stefy II, III i IV) oraz NW-SE dla strefy II.
\end{abstract}

Słowa kluczowe: pasywne pozyskiwanie ciepła, pasywne chłodzenie, dobrostan zwierząt, mikroklimat

\section{WSTĘP}

Zapewnienie odpowiedniego mikroklimatu w budynkach inwentarskich stanowi kompleksowe zagadnienie. Uzyskanie optymalnych warunków temperatury, ruchu powietrza (wentylacji), wilgotności i promieniowania słonecznego jest wyzwaniem zarówno na etapie projektowania budynku, jak i utrzymania. Maksymalną wydajność produkcji uzyskuje się w warunkach jak najbardziej zbliżonych do neutralnych, tzn. niezależnych od otoczenia, w zakresie temperatury odpowiedniej dla danego gatunku hodowanego zwierzęcia i jego stadium rozwoju. Stan neutralny termicznie to zakres temperatury między dolną a górną temperaturą krytyczną. Zwierzęta utrzymują normalną temperaturę ciała, bez potrzeby wykorzystania energii pozyskanej z paszy na przyspieszenie lub spowolnienie standardowego tempa metabolizmu (Firfiris, Martzopoulou i Kotsopoulos, 2019; Martzopoulou, Firfiris i Kotsopoulos, 2020). Uzyskanie tego rodzaju warunków wiąże się utrzymaniem równowagi cieplnej między zwierzętami a ich otoczeniem, które jest wypadkową zysków ciepła z promieniowania słonecznego, ciepła wytwarzanego przez zwierzęta oraz strat ciepła przez przegrody zewnętrzne (Albright, 1990). Optymalizacja produkcji zwierzęcej wymaga więc zbilansowania zysków i strat cieplnych, a te z kolei wynikają z zastosowanych rozwiązań konstrukcyjno-materiałowych oraz zewnętrznych warunków meteorologicznych. Badania prowadzone dla budynku zlokalizowanego w brytyjskim Staffordshire (Jackson, Guy, Edwards, Sturm i Bull, 2017) pokazują, że w świetle przewidywanego 
wzrostu temperatury na lata 2030, 2050 i 2080, utrzymanie wymaganej temperatury wewnętrznej będzie coraz większym wyzwaniem.

Utrzymanie optymalnej temperatury oraz wilgotności w budynku inwentarskim tradycyjnie uzyskuje się przede wszystkim poprzez zastosowanie prostej formy przestrzennej, niewielkiego nachylenia dachu, ograniczenia liczby i powierzchni otworów okiennych, ale przede wszystkim przez skonstruowanie przegród zewnętrznych, tj. ściany i dach, o bardzo wysokim wskaźniku izolacyjności cieplnej. Duża izolacyjność cieplna przegród budynków zazwyczaj kojarzy się z ochroną przed nadmiernym schładzaniem wnętrza $\mathrm{w}$ okresie niskiej temperatury, lecz prawidłowo zaprojektowane przegrody zewnętrzne chronią również wnętrze przed nadmiernym wzrostem temperatury w okresie letnim. Szczególną uwagę skupia się obecnie na bardzo dobrym izolowaniu cieplnym dachu, który jest bezpośrednio poddawany operacji słonecznej, a tym samym może być źródłem nadmiernego zwiększania temperatury wewnątrz budynku inwentarskiego. Systemowe rozwiązania w strukturze materiałowo-konstrukcyjnej budynku pozwalają również na dogrzewania ciepłem słonecznym wnętrza budynku, a tym samym ograniczenie zapotrzebowania na moc grzewczą ze sztucznych źródeł ciepła (Żelazny, 2008).

Rozwiązania materiałowo-konstrukcyjne mogą i powinny być wspomagane dodatkowymi działaniami. Firfilis i in. (2019) podzielili je na dwie podstawowe kategorie:

- techniki pasywnego chłodzenia polegające na bezpośrednim zacienianiu budynku stałymi lub okresowo wykorzystywanymi formami zacienienia,

- techniki pasywnego chłodzenia, których celem jest pośrednie ograniczenie promieniowania słonecznego.

W pierwszym przypadku to przede wszystkim nasadzenia z drzew liściastych, odpowiednio zaprojektowane pod względem wysokości oraz odległości od budynku, tak by nie ograniczać naturalnej wentylacji w budynku (Alberta Agriculture and Rural Development, 2014; Valtorta, 2010). W regionach o silnej ekspozycji słonecznej w okresach letni, głównie w hodowli bydła i owiec, stosowane są również sztuczne pokrywy zacieniające rozpościerane nad budynkiem lub w jego sąsiedztwie. Do tego typu rozwiązań moż- na też zaliczyć okapy, które w okresie letnim ograniczają penetrację promieni słonecznych.

Do pasywnych technik chłodzenia pośrednio wpływających na termikę budynku należą forma przestrzenna budynku oraz jego położenie, w tym przede wszystkim orientacja względem stron świata. Badania pokazują, że optymalne pod względem ilości absorbowanego ciepła są budynki na rzucie prostokąta, przykryte dachem o nachylenie ok. $15^{\circ}$ (Mrema, Gumbe, Chepete i Agullo, 2011; Vox, Maneta i Schettini, 2016) oraz pokryte materiałem o wysokim współczynniku odbicia promieniowania słonecznego (albedo) i z duża emisja termiczną. Dla tzw. chłodnych dachów (ang. cool roofs) wartości te wynoszą odpowiednio co najmniej 0,70 oraz 0,75 (Bianchi, Desjarlais, Miller i Petrie, 2007).

Wpływ usytuowania budynku na absorpcję energii słonecznej jest zależny od warunków lokalnych, takich jak: ukształtowanie terenu, pokrycie terenu, temperatura i kierunek przeważających wiatrów. Dodatkowym czynnikiem jest też usytuowanie budynku względem stron świat. Warunki zabudowy i zagospodarowania działki rzadko umożliwiają swobodne usytuowanie budynku, niemniej jednak należy dążyć do optymalnego jego położenia, analizując ten aspekt na etapie przedprojektowym.

Badania uwzględniające orientację budynku inwentarskiego względem stron świata prowadzono przede wszystkim dla obszarów o gorącym klimacie. Wielu autorów jest zgodnych, że budynek inwentarski powinien być ustawiony osią poziomą prostopadle do kierunku panujących lokalnie wiatrów, dzięki czemu można zwiększyć naturalną wymianę powietrza (Mescher i Veenhuizen, 2006; Liberati i Zappavigna, 2010).

W Polsce dystrybucja promieniowania słonecznego jest zróżnicowana przestrzennie oraz w ujęciu czasowym. Na sześć miesięcy w okresach wiosennym i letnim (od kwietnia do września) przypada $80 \%$ rocznego nasłonecznienia. Maksymalny okres nasłonecznienia latem wynosi $16 \mathrm{~h}$. Gęstość promieniowania słonecznego na płaszczyźnie poziomej wynosi od 950 do $1250 \mathrm{kWh} \cdot \mathrm{m}^{-2}$ (Żochowska, Kingsbury i Kobuszynska, 2012). Dla warunków polskich (przeważające zachodnie wiatry) na ogół zalecane jest usytuowanie budynku dłuższą osią w kierunku N-S z dopuszczeniem niewielkiego odchylenia (Marciniak, 2008). Powstaje pytanie, czy tak ogólnie sformułowana zasada 
nie wymaga doprecyzowania w zależności od lokalizacji planowanego obiektu w danej strefie klimatycznej.

Dla okresu letniego (czerwiec-wrzesień) badania dla budynków dla bydła prowadzili Angrecka, Herbut, Nawalany i Sokołowski (2017). Uwzględniono w nich położenie geograficzne, azymut i kąty nasłonecznienia. Analizowano budynki o orientacjach N-S i E-W oraz odchylone o $30 \%$ od osi N-S. Przedmiotem badań była też zależność między rozmiarem okapu a nasłonecznieniem. Za najkorzystniejsze uznano wydłużenie okapu do $1 \mathrm{~m}$ oraz odchylenie o $30 \%$ od osi N-S. Oceną zróżnicowania temperatury powietrza w budynkach chlewni z pasywnym systemem zysków bezpośrednich oraz naturalnym rozdziałem pozyskanego ciepła przez otwory komunikacyjne zajmował się Żelazny (2008). Jego badania dotyczyły pozyskiwania, akumulacji i rozdziału ciepła słonecznego do pomieszczeń w różnych częściach budynku usytuowanego dłuższą osią w kierunku N-S. Autor stwierdził, że dogrzewanie ciepłem słonecznym pomieszczeń inwentarskich w celu poprawy warunków termicznych lub zmniejszenia zapotrzebowania na moc grzewczą ze sztucznych źródeł ciepła jest możliwe tylko w przypadku zastosowania systemowych rozwiązań w strukturze materiałowo-konstrukcyjnej budynku. W celu zabezpieczenia budynku przed solarnym nadmiernym nagrzewaniem się w okresie letnim autor zalecał stosowanie różnego rodzaju rozwiązań technicznych (żaluzje, rolety) i biologicznych (zadrzewienia z gatunków liściastych).

Implementacja różnych form pasywnego (biernego) pozyskiwania ciepła oraz schładzania budynku może być efektywna, a co za tym idzie opłacalna ekonomicznie. Poza tym ograniczenie zapotrzebowania na dodatkowe źródła ciepła, a przede wszystkim na mechaniczną wentylację ogranicza emisję dwutlenku węgla, jest to więc przyjazne dla środowiska przyrodniczego.

Celem badań było określenie wpływu ustawienia budynku chlewni na działce siedliskowej na zyski solarne w okresie niskiej i wysokiej temperatury na zewnątrz w wybranych regionach Polski. W zimie mniejsze zyski solarne przekładają się na większą potrzebę uzupełnienia energii cieplnej przez system ogrzewania. Nadmiar zysków solarnych w okresie letnim może sprzyjać podwyższaniu temperatury wewnętrznej, która w krytycznych przypadkach prowadzi do powstawaniu u zwierząt stresu cieplnego, co zazwyczaj powoduje konieczność zastosowania dodatkowej wentylacji mechanicznej. Powyższe skrajne sytuacje mają szkodliwy wpływ na wydajność produkcji, dobrostan zwierząt oraz ogólną efektywność energetyczną procesu produkcyjnego (Jackson i in., 2017). Celem praktycznym pracy było wskazanie usytuowania chlewni względem stron świata optymalnego dla analizowanych stref klimatycznych.

\section{MATERIAŁ I METODY}

W badaniach wykorzystano metodykę wyznaczania zysków ciepła od promieniowania słonecznego zgodnie z normą PN-EN 13790. Zyski ciepła od promieniowania słonecznego dla analizowanego budynku wyznaczono według wzoru:

$$
Q_{s o l}=\sum_{i} C_{i} \cdot A_{i} \cdot I_{i} \cdot F_{s h} \cdot F_{s h, g l} \cdot g_{g l}\left[\mathrm{kWh} \cdot \text { miesiąc }^{-1}\right]
$$

gdzie:

$C_{i} \quad$ - udział pola powierzchni oszklonej do całkowitego pola powierzchni okna [-],

$A_{i} \quad$ - pole powierzchni okna lub drzwi balkonowych $\mathrm{w}$ świetle otworu w przegrodzie $\left[\mathrm{m}^{2}\right]$,

$I_{i} \quad$ - wartość energii promieniowania słonecznego w rozpatrywanym miesiącu na płaszczyznę pionową, w której usytuowane jest okno o powierzchni $A_{i}$, według danych dotyczących najbliższego punktu pomiarów promieniowania słonecznego $\left[\mathrm{kWh} \cdot \mathrm{m}^{-2} \cdot\right.$ miesiąc $\left.^{-1}\right]$,

$F_{s h}$ - czynnik redukcyjny ze względu na zacienienie od przegród zewnętrznych (ustalono zgodnie z normą PN-EN 13790),

$F_{\text {sh.gl }}$ - czynnik redukcyjny ze względu na zacienienie dla ruchomych urządzeń zacieniających,

$g_{g l} \quad$ - współczynnik przepuszczalności energii promieniowania słonecznego przez oszklenie [-].

Do badań wybrano chlewnie ze względu na ich specyficzne wymagania cieplno-wilgotnościowe zależne od struktury stada oraz technologii chowu. Największe wymagania cieplne odnoszą się do chowu trzody chlewnej na podłodze szczelinowej i w zależności od stadium rozwoju wynoszą: maciory zasuszane $18-20^{\circ} \mathrm{C}$, lochy karmiące $18-22^{\circ} \mathrm{C}$, warchlaki $22-30^{\circ} \mathrm{C}$, tuczniki $18-20^{\circ} \mathrm{C}$. Wymagane jest zachowanie wilgotności powietrza na poziomie $60-70 \%$ (Wardal, Romaniuk i Borusiewicz, 2018). 
Obliczenia wykonano dla teoretycznego budynku chlewni o powierzchni $1125 \mathrm{~m}^{2}$, co odpowiada wymiarom $12,5 \times 90 \mathrm{~m}$. Zgodnie z wymaganiami powierzchnia otworów oświetleniowych powinna być nie mniejsza niż wartość $1: 25$ powierzchni podłogi (wartość dla chowu tuczników - tab. 1). Według tego kryterium powierzchnia otworów okiennych została określona na poziomie $22,68 \mathrm{~m}^{2}$ na dwóch bokach podłużnych ścian ze- wnętrznych, tj. 22 okna o wymiarach $90 \times 90 \mathrm{~cm}$. Łączna powierzchnia otworów okiennych wynosi $45,36 \mathrm{~m}^{2}$.

Dla założonych parametrów analizowanego budynku obliczono miesięczne zyski ciepła od promieniowania słonecznego przenikającego do przestrzeni ogrzewanej przez okna, drzwi lub powierzchnie oszklone bez uwzględnienia energii promieniowania słonecznego (tab. 2).

Tabela 1. Zalecany stosunek powierzchni okien do powierzchni podłogi i natężenie sztucznego oświetlenia (Wardal i in., 2018)

Table 1. Recommended ratio of window area to floor area and intensity of artificial lighting (Wardal et al., 2018)

\begin{tabular}{|c|c|c|}
\hline $\begin{array}{l}\text { Przeznaczenie pomieszczeń } \\
\text { Designation of particular building parts }\end{array}$ & $\begin{array}{l}\text { Oświetlenie dzienne } \\
\text { (okno : podłoga) } \\
\text { Daylighting (window : floor) }\end{array}$ & $\begin{array}{l}\text { Zalecane natężenie oświetlenia } \\
\text { Recommended light intensity } \\
{[1 \mathrm{~lx}]}\end{array}$ \\
\hline $\begin{array}{l}\text { Pomieszczenia zagrodowe, korytarz paszowy } \\
\text { oraz korytarz dla pracowników nadzorujących } \\
\text { Homesteads, feed corridor and corridor for supervisors }\end{array}$ & $1: 15$ & 50 \\
\hline Pomieszczenia pracownicze - Staff rooms & $1: 10$ & 200 \\
\hline $\begin{array}{l}\text { Lochy luźne i prośne, knury - zalecenie ogólne } \\
\text { Loose and covered sows, boars - general recommendation }\end{array}$ & $1: 15$ & 100 \\
\hline $\begin{array}{l}\text { Lochy luźne i knury - miejsce pracy } \\
\text { Loose sows and boars - working area }\end{array}$ & $1: 15$ & 200 \\
\hline Karmiące lochy i prosięta - Farrowing sows and piglets & $1: 15$ & 100 \\
\hline Warchlaki - Weaners & $1: 18$ & 50 \\
\hline Tuczniki - Porkers & $1: 25$ & 50 \\
\hline
\end{tabular}

Tabela 2. Parametry stałe charakteryzujące przeszklenie stolarki okiennej wymagane do ustalenia miesięcznych zysków ciepła od promieniowania słonecznego przenikającego do przestrzeni ogrzewanej przez okna, drzwi lub powierzchnie oszklone w ścianach podłużnych (opracowanie własne)

Table 2. Constant parameters reflecting window glazing required to determine the monthly heat gain from solar radiation penetrating into the space heated by windows, doors or glazed surfaces (own elaboration)

\begin{tabular}{lc}
\hline $\begin{array}{l}\text { Parametry stałe stolarki okiennej } \\
\text { Constant parameters for windows }\end{array}$ & $\begin{array}{c}\text { Ściany I i II } \\
\text { Walls I and II }\end{array}$ \\
\hline$A_{i}\left[\mathrm{~m}^{2}\right]$ & 22,68 \\
\hline$C_{i}[-]$ & 0,70 \\
\hline$g_{g l}[-]$ & 0,75 \\
\hline$F_{s h, g l}[-]$ & 1,00 \\
\hline$F_{s h}[-]$ & 0,91 \\
\hline$A_{i} \cdot C_{i} \cdot F_{s h, g l} \cdot F_{s h} \cdot g_{g l}\left[\mathrm{kWh} \cdot\right.$ miesiąc $\left.^{-1}\right]$ & 10,84 \\
\hline
\end{tabular}


Obliczenia miesięcznych zysków ciepła od promieniowania słonecznego wykonano dla czterech wariantów usytuowania rozpatrywanego budynku względem stron świata $\mathrm{w}$ osiach: $\mathrm{N}-\mathrm{S}, \mathrm{W}-\mathrm{E}$, NW-SE oraz NE-SW (rys. 1). Przyjęto teoretyczne lokalizacje budynku w obrębie trzech stref klimatycznych Polski: II, III i IV (rys. 2). Wybrano strefy największe obszarowo oraz charakteryzujące się największą koncentracją produkcji zwierzęcej.

W nawiązaniu do wybranych do badań stref klimatycznych Polski w pracy wykorzystano dane dotyczące natężenie promieniowania słonecznego na powierzchnię o kącie nachylenia $90^{\circ}$ dla następujących stacji meteorologicznych: Poznań i Zielona Góra

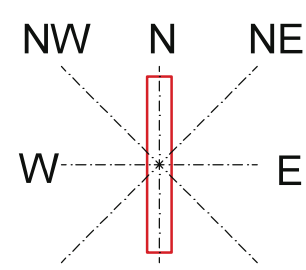

SW S SE
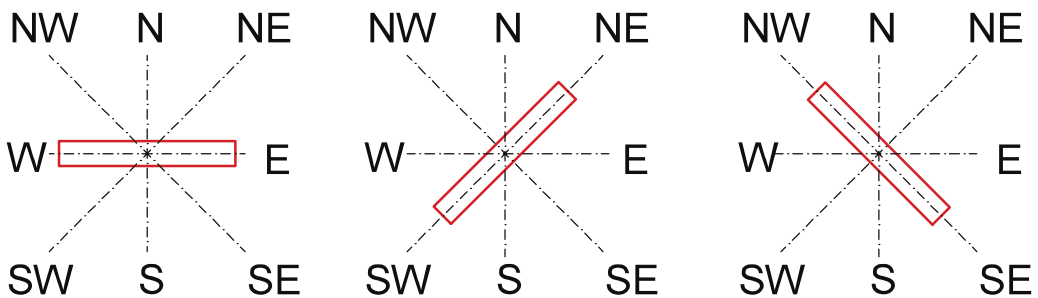

Rys. 1. Rozpatrywane warianty usytuowania budynku inwentarskiego względem stron świata (opracowanie własne)

Fig. 1. Variants of livestock building orientation in relation to the cardinal points (own elaboration)

Rys. 2. Mapa stref klimatycznych Polski według normy PN-EN 12831

Fig. 2. Map of climate zones in Poland according to PN-EN 12831 standard

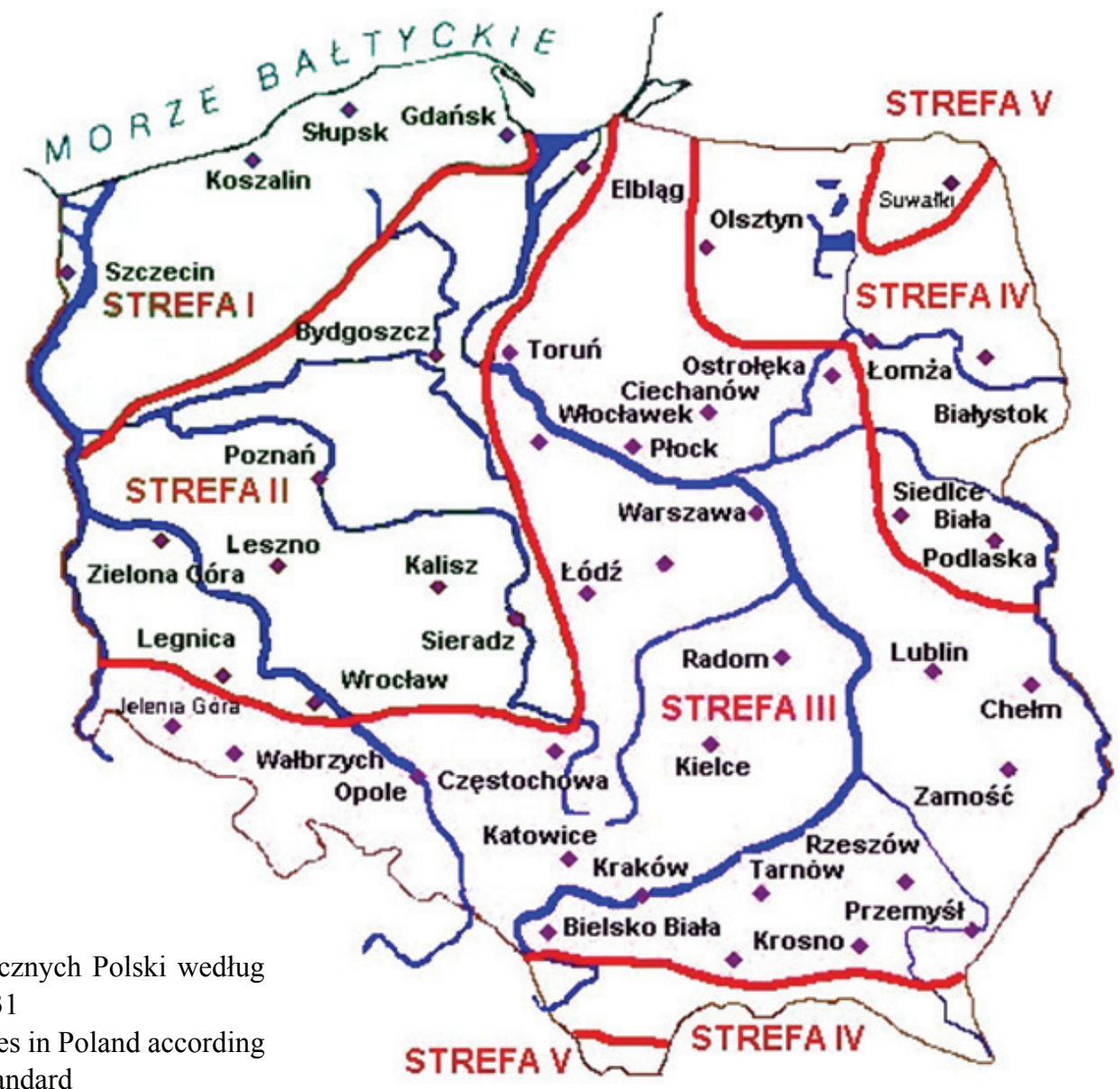


Wiśniewski, K., Pawłat-Zawrzykraj, A. (2020). Wpływ usytuowania budynku inwentarskiego na uzysk ciepła słonecznego. Acta Sci. Pol. Architectura, 19 (3), 29-41. doi: 10.22630/ASPA.2020.19.3.25

w strefie II; Warszawa-Okęcie w strefie III, Białystok w strefie IV (tab. 3).

Ze względu na istotne różnice w zapotrzebowaniu na ciepło w ciągu roku przyjęto podział na następujące podstawowe okresy:
- największego zapotrzebowania na ciepło - od stycznia do marca (okres I) oraz od października do grudnia (okres III);

- małego zapotrzebowania na ciepło - od kwietnia do września (okres II).

Tabela 3. Średnie natężenie promieniowania słonecznego $\left[\mathrm{W} \cdot \mathrm{m}^{-2}\right]$ na powierzchni o kącie nachylenia $90^{\circ}$ na stacjach meteorologicznych Zielona Góra, Warszawa-Okęcie, Poznań, Białystok (dane Ministerstwa Inwestycji i Rozwoju, https://archiwum.miir.gov.pl/media/51869/wmo122950iso_stat.txt; dostęp: 20.07.2020)

Table 3. Average intensity of solar radiation $\left[\mathrm{W} \cdot \mathrm{m}^{-2}\right]$ on an area with an inclination angle of $90^{\circ}$ at the Zielona Góra, Warszawa-Okęcie, Poznań, Białystok weather stations (Ministry of Investment and Economic Development data, https://archiwum.miir.gov.pl/media/51869/wmo122950iso_stat.txt; accessed: 20.07.2020)

\begin{tabular}{|c|c|c|c|c|c|c|c|c|c|}
\hline $\begin{array}{l}\text { Stacja meteo } \\
\text { Weather station }\end{array}$ & $\begin{array}{l}\text { Miesiąc } \\
\text { Month }\end{array}$ & $\mathrm{N}$ & $\mathrm{NE}$ & E & SE & S & SW & W & NW \\
\hline \multirow{12}{*}{ Poznań } & 1 & 19241 & 19241 & 21238 & 35265 & 41961 & 35348 & 21297 & 19241 \\
\hline & 2 & 26199 & 26291 & 31767 & 42636 & 46701 & 38852 & 29029 & 26202 \\
\hline & 3 & 42750 & 45132 & 58272 & 74973 & 83279 & 72005 & 55748 & 44530 \\
\hline & 4 & 70449 & 76410 & 89941 & 100343 & 101065 & 92981 & 82760 & 73618 \\
\hline & 5 & 89166 & 99104 & 112763 & 118903 & 117014 & 118943 & 112972 & 99359 \\
\hline & 6 & 105766 & 115739 & 126620 & 127463 & 120112 & 122194 & 121404 & 113630 \\
\hline & 7 & 103360 & 114830 & 125457 & 125280 & 116839 & 117409 & 115626 & 108797 \\
\hline & 8 & 83226 & 89710 & 100133 & 105883 & 104123 & 101087 & 95324 & 87706 \\
\hline & 9 & 58860 & 60783 & 68623 & 77966 & 82774 & 77289 & 68053 & 60653 \\
\hline & 10 & 36131 & 36162 & 39164 & 47711 & 54433 & 50677 & 41388 & 36342 \\
\hline & 11 & 19772 & 19772 & 21476 & 32009 & 39347 & 35218 & 23745 & 19772 \\
\hline & 12 & 19241 & 19241 & 21238 & 35265 & 41961 & 35348 & 21297 & 19241 \\
\hline \multirow{12}{*}{ Zielona Góra } & 1 & 17955 & 17955 & 19282 & 27386 & 31283 & 27373 & 19272 & 17955 \\
\hline & 2 & 21803 & 21966 & 26735 & 36902 & 42198 & 35711 & 25777 & 21803 \\
\hline & 3 & 46657 & 47864 & 55772 & 65790 & 69060 & 60861 & 51750 & 47104 \\
\hline & 4 & 72088 & 77225 & 87079 & 94383 & 95824 & 92291 & 84650 & 75881 \\
\hline & 5 & 87730 & 95822 & 106328 & 109920 & 105981 & 105233 & 101386 & 93520 \\
\hline & 6 & 101624 & 110696 & 118393 & 117309 & 110549 & 113286 & 113130 & 107277 \\
\hline & 7 & 99880 & 108067 & 116359 & 116564 & 110143 & 110151 & 109041 & 104132 \\
\hline & 8 & 83602 & 88336 & 96618 & 102202 & 102489 & 100278 & 94620 & 87434 \\
\hline & 9 & 56993 & 58475 & 65459 & 72803 & 76123 & 71948 & 65383 & 59222 \\
\hline & 10 & 34608 & 34751 & 40978 & 52190 & 57292 & 49433 & 39056 & 34791 \\
\hline & 11 & 19512 & 19512 & 20866 & 27068 & 31070 & 28301 & 21738 & 19512 \\
\hline & 12 & 17373 & 17373 & 17728 & 22601 & 24766 & 22600 & 17727 & 17373 \\
\hline
\end{tabular}


Wiśniewski, K., Pawłat-Zawrzykraj, A. (2020). Wpływ usytuowania budynku inwentarskiego na uzysk ciepła słonecznego. Acta Sci. Pol. Architectura, 19 (3), 29-41. doi: 10.22630/ASPA.2020.19.3.25

Tabela 3, cd. / Table 3, cont.

\begin{tabular}{|c|c|c|c|c|c|c|c|c|c|}
\hline $\begin{array}{l}\text { Stacja meteo } \\
\text { Weather station }\end{array}$ & $\begin{array}{l}\text { Miesiąc } \\
\text { Month }\end{array}$ & $\mathrm{N}$ & NE & E & $\mathrm{SE}$ & S & SW & W & NW \\
\hline \multirow{12}{*}{$\begin{array}{l}\text { Warszawa } \\
\text { Okęcie }\end{array}$} & 1 & 21215 & 21215 & 23781 & 36976 & 42377 & 35382 & 22654 & 21215 \\
\hline & 2 & 25556 & 25560 & 30316 & 39465 & 43845 & 37612 & 29072 & 25653 \\
\hline & 3 & 49314 & 50400 & 60328 & 72337 & 75781 & 65528 & 55256 & 50035 \\
\hline & 4 & 69001 & 73481 & 83772 & 91229 & 91948 & 87481 & 80623 & 72776 \\
\hline & 5 & 94223 & 105591 & 119230 & 123107 & 116562 & 115826 & 111366 & 101751 \\
\hline & 6 & 100296 & 109514 & 121408 & 124392 & 119523 & 123109 & 121406 & 110795 \\
\hline & 7 & 103727 & 115765 & 128871 & 130639 & 122667 & 124096 & 121712 & 112185 \\
\hline & 8 & 88775 & 97388 & 110036 & 116699 & 115216 & 113390 & 106225 & 95307 \\
\hline & 9 & 61523 & 63298 & 69620 & 77342 & 82852 & 79904 & 71775 & 63785 \\
\hline & 10 & 36646 & 36756 & 40044 & 48980 & 55856 & 51806 & 42118 & 36862 \\
\hline & 11 & 18022 & 18022 & 19296 & 24269 & 27615 & 25342 & 20055 & 18022 \\
\hline & 12 & 15549 & 15549 & 16029 & 21025 & 23280 & 21006 & 16016 & 15549 \\
\hline \multirow{12}{*}{ Białystok } & 1 & 16621 & 16621 & 17689 & 26798 & 31390 & 27330 & 18065 & 16621 \\
\hline & 2 & 19661 & 19661 & 24546 & 34680 & 38689 & 31558 & 22343 & 19667 \\
\hline & 3 & 44456 & 45407 & 53018 & 62951 & 66414 & 58506 & 49586 & 44998 \\
\hline & 4 & 67540 & 72441 & 81634 & 88016 & 88435 & 84351 & 77581 & 70375 \\
\hline & 5 & 82570 & 92897 & 106619 & 112036 & 108768 & 110918 & 105906 & 93007 \\
\hline & 6 & 98772 & 110604 & 122118 & 122759 & 114660 & 113784 & 110726 & 103470 \\
\hline & 7 & 97053 & 108048 & 119738 & 121606 & 114238 & 112722 & 109164 & 101977 \\
\hline & 8 & 82851 & 88503 & 100486 & 108519 & 107238 & 100264 & 92732 & 85792 \\
\hline & 9 & 55048 & 58182 & 69636 & 81789 & 87131 & 79254 & 67353 & 57489 \\
\hline & 10 & 31294 & 31386 & 34272 & 42429 & 48759 & 45157 & 36281 & 31499 \\
\hline & 11 & 15817 & 15817 & 17521 & 23244 & 25906 & 22659 & 17108 & 15817 \\
\hline & 12 & 15043 & 15043 & 15196 & 17548 & 18748 & 17778 & 15359 & 15043 \\
\hline
\end{tabular}

W pracy ustalono usytuowanie budynku, w jakim uzyskuje się największy zysk energii od słońca w danej strefie klimatycznej w okresie największego zapotrzebowania na ciepło (okresy I i III). Ponadto wskazano warianty usytuowania budynku, dla których obliczono najmniejsze sumaryczne zyski ciepła w okresie letnim, w którym zyski energii cieplnej od słońca mogą być przyczyną podwyższenia temperatury wewnętrznej w chlewni (okres II).

\section{WYNIKI I DYSKUSJA}

Zyski solarne w okresie jesienno-zimowym (październik-marzec) stanowią korzystną dawkę energii cieplnej, wpływającą pozytywnie na wyniki bilansu cieplnego chlewni. Inaczej jest od kwietnia do września, gdy uzyskiwana ilość energii wpływa niekorzystnie na bilans cieplny chlewni i może być przyczyną niepotrzebnego zwiększania temperatury wewnętrznej, aż 
do osiągnięcia temperatury sprzyjającej powstawaniu stresu cieplnego. O ile w kwietniu i maju bywają okresy niskiej temperatury, o tyle zyski energii słonecznej mogą w tym czasie znacząco uzupełniać braki energetyczne związane z dogrzewaniem pomieszczeń, w których przebywają zwierzęta. Największe zyski ciepła występują oczywiście w miesiącach letnich takich jak czerwiec, lipiec, sierpień (tab. 3). Jak wspomniano, w tym okresie zyski solarne są wręcz utrudnieniem w utrzymaniu optymalnej temperatury wewnętrznej na poziomie $20^{\circ} \mathrm{C}$.

Wyniki obliczeń zysków ciepła z promieniowania słonecznego w poszczególnych miesiącach dla analizowanego modelowego budynku inwentarskiego w przyjętych do analizy lokalizacjach przedstawiono na rysunkach 3-6 oraz w tabelach 4 i 5 .

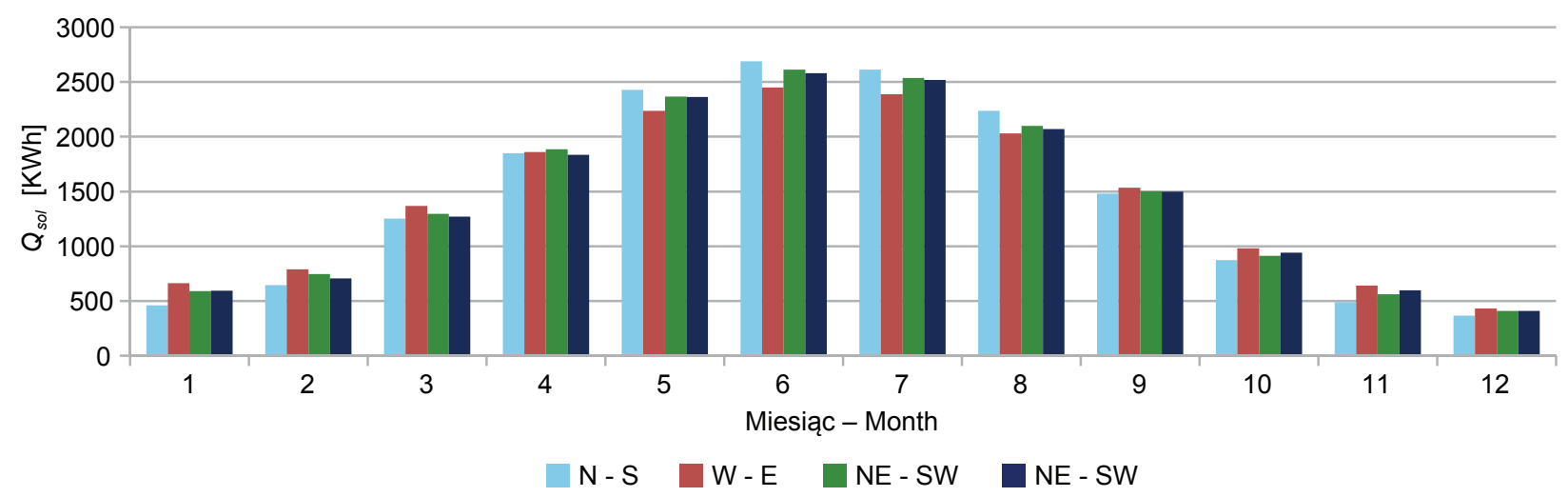

Rys. 3. Rozkład uzysków energii od słońca przez stolarkę okienną w poszczególnych miesiącach i różnym położeniu budynku względem stron świata na podstawie danych ze stacji meteorologicznej Poznań (opracowanie własne)

Fig. 3. Distribution of energy gain from solar radiation through window joinery in individual months and different location of the building in relation to cardinal points based on data from the weather station Poznań (own elaboration)

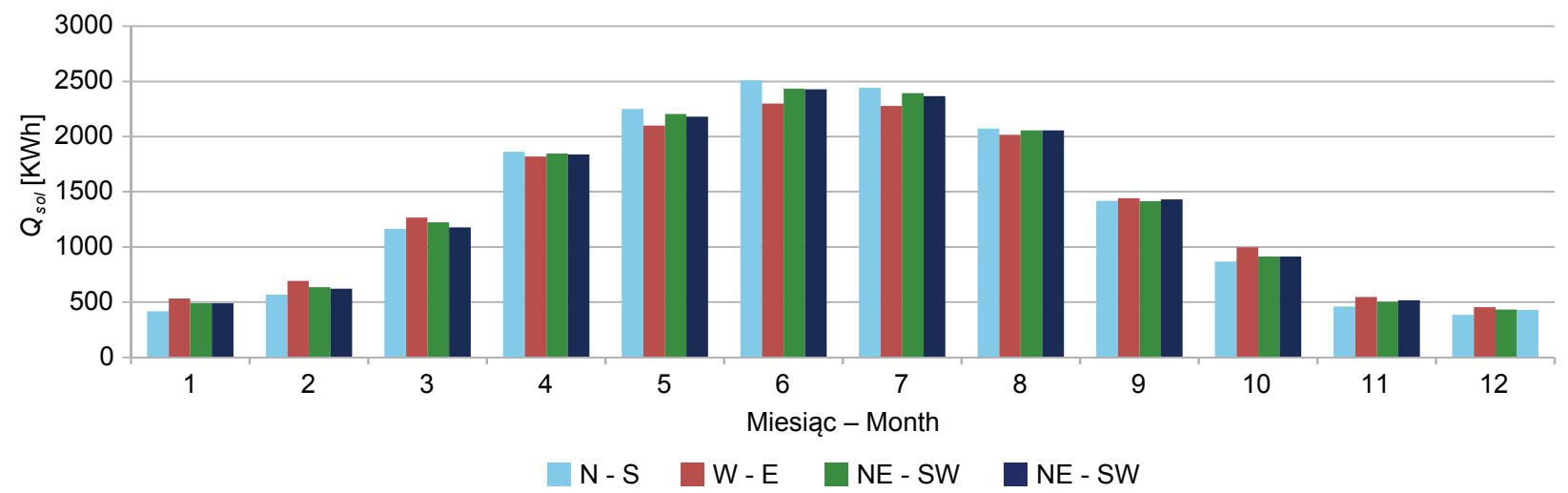

Rys. 4. Rozkład uzysków energii od słońca przez stolarkę okienną w poszczególnych miesiącach i różnym położeniu budynku względem stron świata na podstawie danych ze stacji meteorologicznej Zielona Góra (opracowanie własne)

Fig. 4. Distribution of energy gain from solar radiation through window joinery in individual months and different location of the building in relation to cardinal points based on data from the weather station Zielona Góra (own elaboration) 


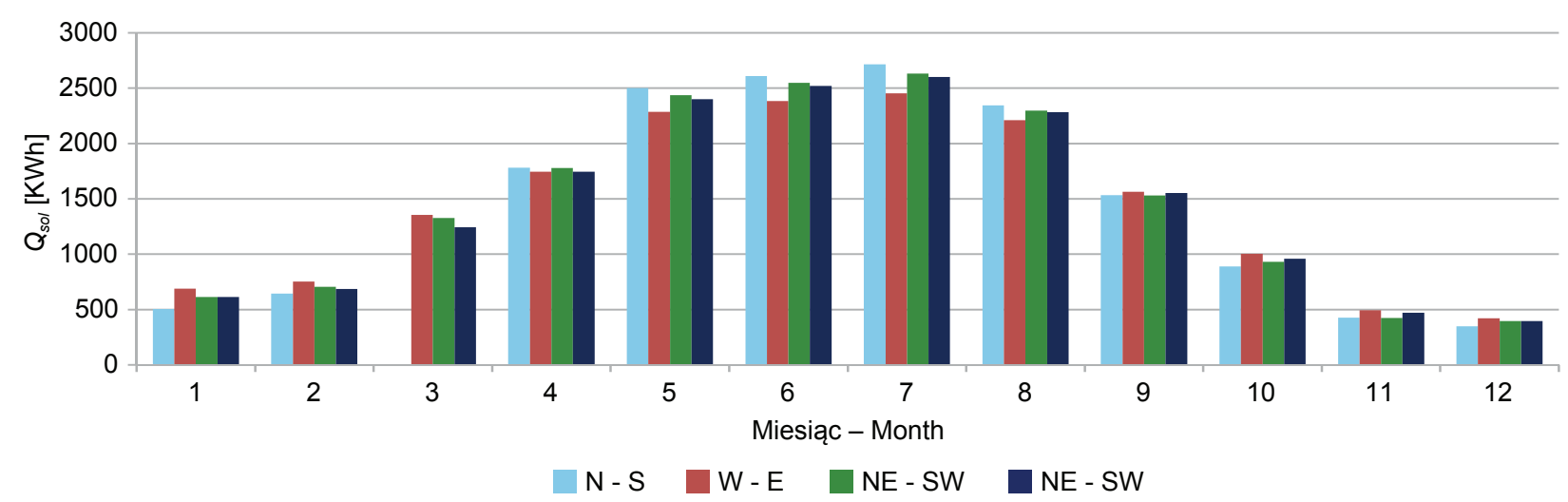

Rys. 5. Rozkład uzysków energii od słońca przez stolarkę okienną w poszczególnych miesiącach i różnym położeniu budynku względem stron świata na podstawie danych ze stacji meteorologicznej Warszawa-Okęcie (opracowanie własne)

Fig. 5. Distribution of energy gain from solar radiation through window joinery in individual months and different location of the building in relation to cardinal points based on data from the weather station Warszawa-Okęcie (own elaboration)

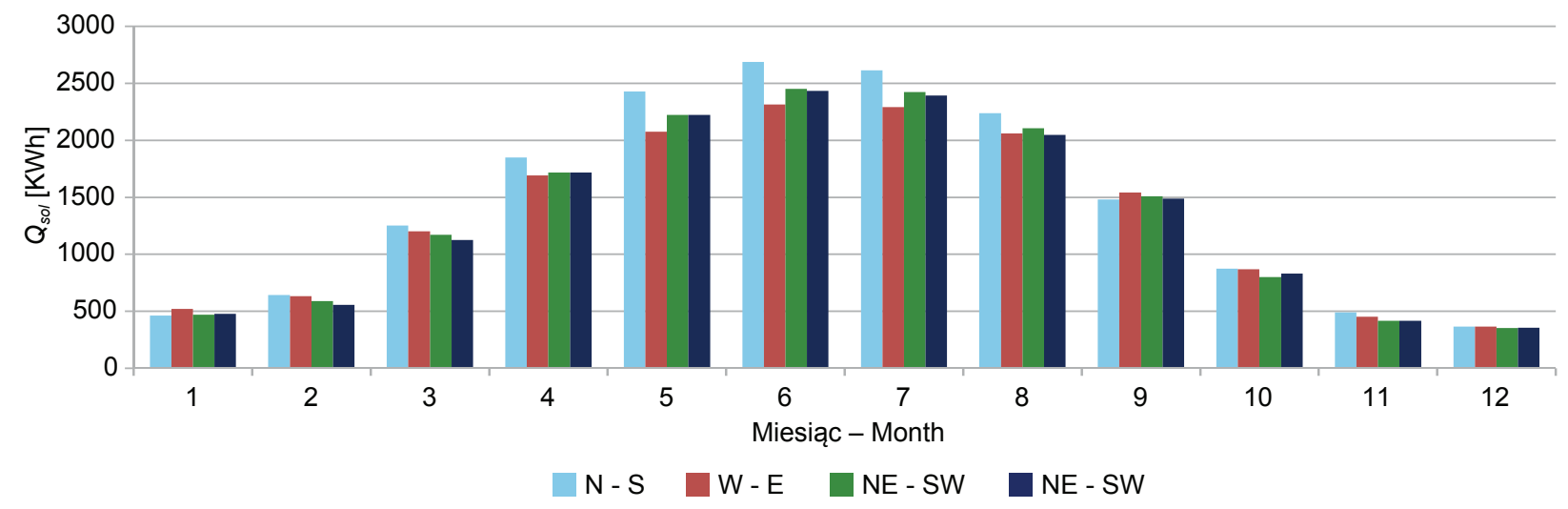

Rys. 6. Rozkład uzysków energii od słońca przez stolarkę okienną w poszczególnych miesiącach i różnym położeniu budynku względem stron świata na podstawie danych ze stacji meteorologicznej Białystok (opracowanie własne)

Fig. 6. Distribution of energy gain from solar radiation through window joinery in individual months and different location of the building in relation to cardinal points based on data from the weather station Białystok (own elaboration)

Na podstawie uzyskanych wyników można stwierdzić, że w przypadku obliczeń wykonanych dla lokalizacji w strefie II - dane dla stacji meteorologicznej Poznań (rys. 3, tab. 5 i 6), najbardziej korzystnym pod względem zysków ciepła od słońca zarówno w okresie jesienno-zimowym, jak i w letnim jest kierunek w osi NW-SE.

Wyniki dla strefy II ze stacji meteorologicznej Zielona Góra (rys. 4, tab. 5 i 6) sugerują, że usytuowanie budynku w osi $\mathrm{N}-\mathrm{S}$ generuje największe zyski ciepła od słońca w okresie jesienno-zimowym. Takie położenie jest tradycyjnie uznawane za najkorzystniejsze. Przykładowo różnica w wartości zysków ciepła między kierunkiem N-S a W-E wynosi $21,5 \%$. Jednocześnie zyski ciepła dla wariantu N-S od kwietnia do września są nieznacznie większe niż w pozostałych wariantach, a różnica w odniesieniu do kierunku W-E wynosi tylko 4,78\%. Najmniejsze zyski ciepła dla okresu letniego uzyskano dla położenia w osi W-E. 


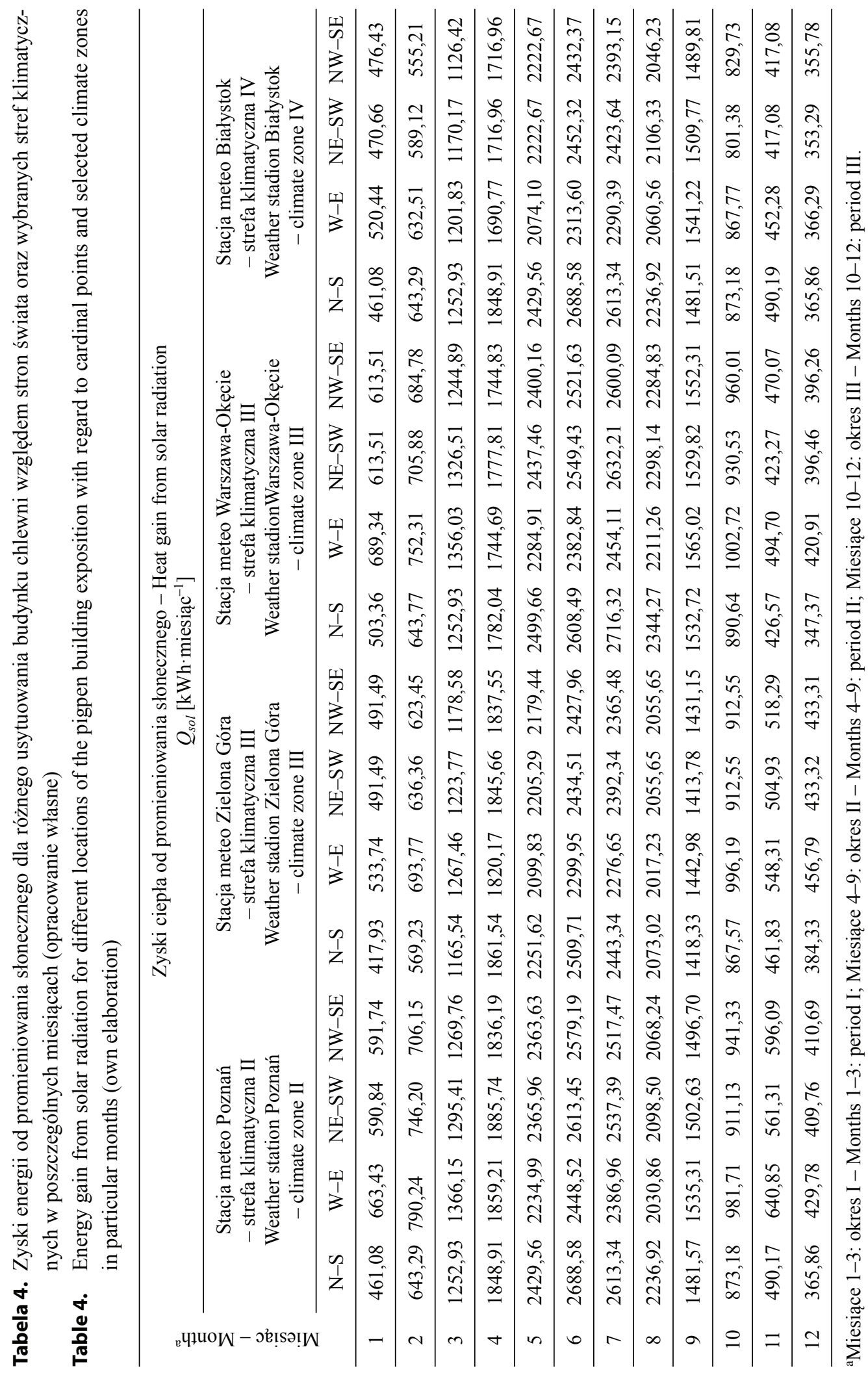


Wiśniewski, K., Pawłat-Zawrzykraj, A. (2020). Wpływ usytuowania budynku inwentarskiego na uzysk ciepła słonecznego. Acta Sci. Pol. Architectura, 19 (3), 29-41. doi: 10.22630/ASPA.2020.19.3.25

Tabela 5. Zbiorcze zestawienie zysków od słońca w analizowanych strefach klimatycznych i przy różnych usytuowaniach budynku względem stron świata (opracowanie własne)

Table 5. Aggregate summary of solar gain in the analysed climate zones and different locations of the building with regard to cardinal points (own elaboration)

\begin{tabular}{|c|c|c|c|c|c|c|c|c|}
\hline \multirow{2}{*}{$\begin{array}{l}\text { Strefa klimatyczna } \\
\text { - stacja meteo } \\
\text { Climate zone } \\
\text { - weather station }\end{array}$} & \multicolumn{2}{|c|}{$\mathrm{N}-\mathrm{S}$} & \multicolumn{2}{|c|}{ W-E } & \multicolumn{2}{|c|}{ SW-NE } & \multicolumn{2}{|c|}{ NW-SE } \\
\hline & $Q_{\text {sol } 1-3 ; 10-12^{\mathrm{a}}}$ & $Q_{\text {sol } 4-9^{\mathrm{b}}}$ & $Q_{\text {sol 1-3;10-12 }}$ & $Q_{\text {sol } 4-9}$ & $Q_{\text {sol } 1-3 ; 10-12}$ & $\mathrm{Q}_{\text {sol 4-9 }}$ & $Q_{\text {sol } 1-3 ; 10-12}$ & $Q_{s o l ~ 49}$ \\
\hline Strefa II - Poznań & 4086,54 & 13483,51 & 3506,01 & 12495,85 & 4514,67 & 13003,68 & 4515,78 & 12861,43 \\
\hline Strefa II - Zielona Góra & 5727,97 & 12557,56 & 4496,27 & 11956,81 & 4202,43 & 12347,25 & 4157,68 & 12297,24 \\
\hline Strefa III - Warszawa & 4065,64 & 13483,51 & 4716,01 & 12642,83 & 4396,16 & 13224,88 & 4369,52 & 13103,86 \\
\hline Strefa III - Białystok & 4086,54 & 13298,89 & 4041,13 & 11970,66 & 3801,69 & 12431,69 & 3760,65 & 12301,18 \\
\hline
\end{tabular}

aZyski ciepła dla okresów I i III - solar gain in periods I and III.

${ }^{\text {b}}$ Zyski ciepła dla okresu II - solar gain in period II.

Wnioski dotyczące lokalizacji w strefach III i IV (dane dla stacji meteorologicznej Warszawa-Okęcie i Białystok) są zbliżone. Od stycznia do marca oraz od października do grudnia zyski ciepła od słońca są największe w przypadku usytuowania budynku w osi W-E. Z kolei w okresie letnim najmniejsze zyski ciepła od słońca w strefie III są w budynku położonym w osi W-E, a w strefie IV w osi N-S. Przy czym w tym ostatnim przypadku różnica między wartościami dla orientacji N-S i W-E jest nieznaczna i wynosi 9,99\%.

W tabeli 6 pokazano sumaryczne zestawienie najkorzystniejszych wariantów usytuowania budynków w analizowanych strefach klimatycznych. Rozbieżności między optymalnym usytuowaniem dla okresu letniego a jesienno-zimowego widoczne są przede wszystkim w przypadku strefy II dla stacji meteorologicznej Zielona Góra. O ile różnica w okresie letnim w zakresie zysków ciepła od słońca jest niewielka (wspominane 4,78\%), o tyle różnica w okresie zwiększonego zapotrzebowania na ciepło (od października do marca) jest już znacząca, bo wynosi $21,5 \%$. W takim przypadku należałoby rozpatrzyć, co jest korzystniejsze - czy przeznaczenie większej ilości energii na dogrzewanie wnętrza w tzw. okresie grzewczym, czy wykorzystanie form pasywnej ochrony budynku przed przegrzewaniem wnętrza.

We wszystkich analizowanych przypadkach, w pełni optymalnych z punktu widzenia zaprezentowanych wyników, zasadne jest poszukiwanie dodatkowych rozwiązań wpływających na zyski solarne w budyn-

Tabela 6. Najkorzystniejsze warianty usytuowania budynków w analizowanych strefach klimatycznych

Table 6. The most advantageous variants of building location in the analysed climate zones

\begin{tabular}{lccc}
\hline \multirow{2}{*}{$\begin{array}{l}\text { Strefa klimatyczna } \\
\text { Climate zones }\end{array}$} & $\begin{array}{c}\text { Stacja meteo } \\
\text { Weather station }\end{array}$ & $\begin{array}{c}\text { Optymalna orientacja budynku w przyjętych okresach } \\
\text { Optimal orientation of the building in the accepted periods }\end{array}$ \\
\cline { 2 - 4 } & Poznań & $\begin{array}{c}\text { okresy I i III } \\
\text { periods I and III }\end{array}$ & $\begin{array}{c}\text { okres II } \\
\text { period II }\end{array}$ \\
\hline II & Zielona Góra & NW-SE & NW-SE \\
\hline III & Warszawa & N-S & W-E \\
\hline IV & Białystok & W-E & W-E \\
\hline
\end{tabular}


kach inwentarskich. Rozwiązaniem uniwersalnym, które będzie sprawdzać się zarówno w okresie letnim, jak i zimowym, są zewnętrzne rolety okienne. Rolety okienne skutecznie chronią przed nadmierną utratą ciepła przez stolarkę okienną w okresie niskiej temperatury (od zmierzchu do świtu), a w okresie letnim pozwalają na ograniczenie zysków solarnych przy jednoczesnym ograniczeniu dopływu światła dziennego, co może wymagać czasowego doświetlenia wnętrza światłem sztucznym, aby zapewnić odpowiednie natężenie światła związane z obsługą zwierząt. Jednakże rolety zewnętrzne można dowolnie opuszczać lub podnosić w celu uzyskania optymalnych warunków cieplnych oraz doświetlenia wnętrza. Innym rozwiązaniem może być stworzenie osłony biologicznej w formie zadrzewień, tak aby chronić budynek przed penetracją słońca w okresie letnim i jednocześnie umożliwiający dopływ energii cieplnej od słońca w okresie zimowym. Takie rozwiązanie jest możliwe jedynie w przypadku osłony z drzew liściastych lub modrzewi.

\section{PODSUMOWNIE I WNIOSKI}

Analiza zysków ciepła od promieniowania słonecznego w zależności od położenia osi budynku względem stron świata pozwala projektantowi na dostosowanie budynku pod względem zachowania prawidłowego dobrostanu zwierząt (trzody chlewnej) poprzez poprawę ochrony biernej i czynnej przed przegrzewaniem wnętrza oraz odpowiedniego doboru izolacyjności cieplnej przegród, w tym także przegród przeziernych.

Uzyskane teoretyczne wyniki zysków ciepła od słońca przy różnych położeniach osi budynku względem stron świata przeczą powszechnie przyjmowanej w literaturze przedmiotu opinii, że najkorzystniejszy jest wariant osi $\mathrm{N}-\mathrm{S}$. Tego rodzaju orientacja budynku została potwierdzona jedynie $\mathrm{w}$ obliczeniach wykonanych dla strefy II według danych dla stacji meteorologicznej Zielona Góra. Z przedstawionych analiz dla wybranych stref klimatycznych kraju wynika, że znacznie korzystniejszy może być wariant usytuowanie budynku dłuższą osią w kierunku W-E lub NW-SE.

$\mathrm{Z}$ uwagi na to, że zyski ciepła od promieniowania słonecznego są ważnym składnikiem bilansu cieplnego budynku inwentarskiego, w przypadku wstępnych analiz na potrzeby konkretnych budynków inwen- tarskich należy w większym stopniu niż dotychczas brać pod uwagę dane meteorologiczne opisujące lokalne warunki klimatyczne i uzyskane zyski ciepła od promieniowania słonecznego dla danego przypadku. Tego rodzaju dane mogą być pomocne w podejmowaniu wstępnych decyzji na temat usytuowania budynku najkorzystniejszego pod względem zysku ciepła w okresie niskiej temperatury oraz ewentualnego przegrzewania wnętrza w okresie letnim.

\section{Indywidualny wkład autorów}

Koncepcja pracy: K.W. i A.P.-Z.; metodyka: K.W.; oprogramowanie: K.W.; walidacja danych: K.W. i A.P.-Z.; analiza formalna: K.W. i A.P.-Z.; badania: K.W. i A.P.-Z.; kompilacja i opracowanie danych: K.W. i A.P.-Z.; sporządzenie wstepnej wersji artykułu: A.P.-Z.; redakcja i korekta artykułu: A.P.-Z.; wizualizacja i oprawa graficzna: K.W. i A.P.-Z.; nadzór: A.P.-Z.; zarządzanie projektem: A.P.-Z.

Wszyscy autorzy zapoznali się z przeznaczoną do publikacji wersją manuskryptu.

\section{PIŚMIENNICTWO}

Alberta Agriculture and Rural Development (2014). Shelterbelts for livestock farms in Alberta: Planning, planting and maintenance - Open Government. Edmonton: University of Alberta. Pobrano z lokalizacji: https:// open.alberta.ca/dataset/8102ce49-c99d-4713-af482bb0a9ff0da4/resource/3f735573-1905-46af-be33754e180465b0/download/6740700-2014-shelterbeltslivestock-farms-alberta-planning-planting-maintenence-400-092-2.pdf

Albright, L. D. (1990). Environment control for animals and plants. New York: American Society of Agricultural Engineers. Pobrano z lokalizacji: https://www.cabdirect. org/cabdirect/abstract/19912450648

Angrecka, S., Herbut, P., Nawalany, G. i Sokołowski, P. (2017). The impact of localization and barn type on insolation of sidewall stalls during summer. Journal of Ecological Engineering, 18 (4), 60-66. https://doi.org/ $10.12911 / 22998993 / 74398$

Bianchi, M. V., Desjarlais, A. O., Miller, W. A. i Petrie, P. T. W. (2007). Cool roofs and thermal insulation: energy savings and peak demand reduction. W Proceedings of the ASHRAE Conference in Thermal Performance of the Exterior Envelopes of Buildings, 10, 1-6. Clearwater, Fl, 12.2007. ASHRAE Transactions. 
Firfiris, V. K., Martzopoulou, A. G. i Kotsopoulos, T. A. (2019). Passive cooling systems in livestock buildings towards energy saving: A critical review. Energy and Buildings, 202, 109368. https://doi.org/10.1016/ j.enbuild.2019.109368

Jackson, P., Guy, J., Edwards, S.A., Sturm, B. i Bull, S. (2017). Application of dynamic thermal engineering principles to improve the efficiency of resource use in UK pork production chains. Energy and Buildings, 139, 53-62. https://doi.org/10.1016/j.enbuild.2016.12.090

Liberati, P. i Zappavigna, P. (2010). A simulation model to predict the internal climatic conditions in livestock houses as a tool for improving the building design and management. W Proceedings of XVIIth World Congress of the International Commission of Agricultural and Biosystems Engineering (CIGR), Quebec City, 13-17.06.2010. Pobrano z lokalizacji: http://www.csbescgab.ca/docs/meetings/2010/CSBE100548.pdf

Marciniak, A. M. (2008). Ocena poziomu oświetlenia naturalnego w oborach wolnostanowiskowych. Problemy Inżynierii Rolniczej, 16 (2), 109-114.

Martzopoulou, A., Firfiris, V. i Kotsopoulos, T. (2020). Application of urban passive cooling systems and design techniques in livestock buildings. IOP Conference Series: Earth and Environmental Science, 410, 012029. https://doi.org/10.1088/1755-1315/410/1/012029

Mescher, T. M. i Veenhuizen, M. A. (2006). Livestock Housing Ventilation: Natural Ventilation Design and Management for Dairy Housing. Pobrano z lokalizacji: https://www.dairyvietnam.com/en/Housing-Construction/Livestock-Housing-Ventilation-Natural-Ventilation-Design-and-Management-for-Dairy-Housing.html
Mrema, G. C., Gumbe. L. O., Chepete. H. K. i Agullo, J. O. (2011). Rural Structures in the Tropics - Design and Development. Rome: Food and Agriculture Organization of the United Nations. Pobrano z lokalizacji: http://www. fao.org/3/I2433e/i2433e.pdf

PN-EN 12831. Charakterystyka energetyczna budynków. Metoda obliczania projektowego obciążenia cieplnego.

Valtorta, S. (2010). Development of Microclimate Modification Patterns in Animal Husbandry. W K. Stigter (red.), Applied Agrometeorology (pp. 803-805). Springer. https://doi.org/10.1007/978-3-540-74698-0_92

Vox, G., Maneta, A. i Schettini, E. (2016). Evaluation of the radiometric properties of roofing materials for livestock buildings and their effect on the surface temperature. Biosystems Engineering, 144, 26-37. https://doi. org/10.1016/j.biosystemseng.2016.01.016

Wardal, W. J., Romaniuk, W. i Borusiewicz, A. (2018). Innowacyjne rozwiazania technologiczno-budowlane $w$ chowie trzody chlewnej. Łomża: Wydawnictwo Wyższej Szkoły Agrobiznesu.

Żelazny, H. (2008). Temperatura powietrza w przestrzeniach budynków inwentarskich Poddanych ekspozycji słonecznej. Inżynieria Rolnicza, 2 (100), 331-337.

Żochowska, M., Kingsbury, A. i Kobuszyńska, M. (2012). Renewable Energy and Bio-fuel Situation in Poland (GAIN report PL 1235). Warsaw: USDA Foreign Agricultural Service. Pobrano z lokalizacji: https://apps.fas. usda.gov/newgainapi/api/report/downloadreportbyfilen ame?filename $=$ Renewable $\% 20$ Energy $\% 20$ and $\% 20$ Biofuel\%20Situation\%20in\%20Poland_Warsaw_Poland_ 12-28-2012.pdf

\title{
IMPACT OF LIVESTOCK BUILDING LOCATION ON SOLAR HEAT OUTPUT
}

\begin{abstract}
The article concerns the influence of the location of livestock building in relation to the cardinal points and the absorption of solar energy, especially in periods of low and high external temperatures. The starting point was the spatial variation in the distribution of solar radiation in Poland. The methodology of determining heat gains from solar radiation in accordance with PN-EN 13790 standard was applied. The calculations were made for a theoretical pigsty building, for four orientations: the N-S, W-E, NW-SE and NE-SW. Theoretical locations of the building were assumed in three climate zones of Poland: zone II represented by city of Poznań, zone III (Warsaw and Jelenia Góra) and zone IV (Białystok). The obtained results do not entirely confirm the accuracy of the commonly applied principle of N-S building orientation. However, during April-September period this location is indeed favourable in case of some climate zones in Poland (zones II and IV). In periods of lower temperatures the most optimal is W-E orientation (zones II, III and IV) and NW-SE for zone II.
\end{abstract}

Key words: passive heating recovery, passive cooling, animal welfare, microclimate 